\title{
Book Selection Policies in the College Library: A Reappraisal
}

\section{Charles A. Gardner}

Historically, faculty have been largely responsible for book selection in academic libraries. Not until the 1950s and early 1960s did university libraries, because of expanding budgets and publication output, alter this practice by adding staff bibliographers. Meanwhile, colleges still retain the older tradition of faculty control of book selection and book funds. Changing conditions make this practice increasingly suspect. It is time for librarians in colleges to follow the lead of their university colleagues by taking control of book funds and establishing authority over the selection process.

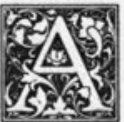

persistent, largely unchallenged tenet of college library acquisitions policy is that which assumes the dominance of teaching faculty in the book selection process. Historically, academic librarians have accepted not only that teaching faculty would play an important role in library acquisitions but also that they would be chiefly responsible for library book purchases and collection building. Until quite recently, this has been true regardless of library size and whether or not materials were intended for undergraduates or advanced scholars and researchers. In recent years, however, university librarians have assumed the major role in book selection in their institutions. But in college libraries, especially those in small undergraduate institutions, faculty dominance in book selection is still generally considered the wisest way to build strong, relevant, and balanced collections. The time has come to challenge this particular orthodoxy.

Recently, the convergence of a number of factors has placed the acquisitions process under severe stress. These factors include the relentless rise in book prices that yearly outstrips national inflation rates; the persistent trend toward smaller increases in most college book budgets; the virtual disappearance of grant funds for acquisition; the drying up of Title II-A federal support; and the awesome annual leap in journal subscription prices that consumes an ever larger portion of an already hard-pressed materials budget.

In the final analysis, the acquisition of library materials always has been the responsibility of the librarian. It is the librarian who has been held accountable, and rightly so, for the growth, balance, and adequacy of the college library's collection. Today, getting the right books on the shelves-those carefully selected materials that meet undergraduate needs and provide balance and strength throughout the collection-has never been more difficult, particularly in the small college library. Yet college librarians still apportion book funds to faculty and rely heavily on them for book selection. To continue to turn over to faculty a major portion of the book budget in these times of increasing budgetary stress is a practice that must be questioned.

The history of American acquisition pol-

Charles A. Gardner is director of libraries at Hastings College, Hastings, Nebraska 68901. 
icies and practices was thoroughly researched by Danton in $1963 .{ }^{1}$ In Book Selection and Collections, he demonstrates how American academic library acquisitions practices developed in the nineteenth century, were modeled closely on those of the German university libraries. Because it was common practice in German academic libraries to turn over available book funds to the various faculties and faculty committees for selection purposes, this became the prevailing pattern in American libraries as well. ${ }^{2}$

The practice of vesting primary authority for academic library collection building in the teaching faculty was so widely accepted by 1926 that the editors of the American Library Association's survey of American libraries could state, "in libraries reporting, practically complete control of departmental allocations is vested in the departments, subject to such centralizing supervision on the part of the library as may be necessary. ${ }^{\prime \prime 3}$ A few years later the U.S. Office of Education reported that of forty-eight libraries reporting to a Survey of Land Grant Colleges and Universities, thirty-five stated that they divided their book fund among academic departments. ${ }^{4}$ Randall, the author of one of the first widely used textbooks on college librarianship, endorsed this practice stating that "the initiating of the purchase usually comes from the faculty, who indicate to the librarian the titles to be acquired on their individual budgets. ${ }^{15}$ Although an occasional voice questioned this orthodoxy or warned of the dangers of faculty predominance, ${ }^{6}$ the literature of the $1930 \mathrm{~s}$ centers not on the rightness or wrongness of the practice but on how best to allocate funds.

Through the 1940s and 1950s, conventional wisdom continued to accept the preeminent responsibility of faculty in book selection. Writers of the period wrestled with the problem of equitable allocation while acknowledging that the major role of librarians in the selection process was that of filling gaps, acquiring basic reference materials, and purchasing general and recreational reading. Shortly after World War II, in a "state of the art" pronouncement, leaders in the field of aca- demic librarianship stated that the "policy of book selection by members of the faculty ... is well established in American colleges and universities.... This has been, and is, sound and sensible practice even though faculty members sometimes lack information about the literature of their fields and knowledge of book selection."

Although there were some who were beginning to question the wisdom of this traditional split in acquisitions responsibilities, university as well as college libraries confirmed the accepted orthodoxy. Of thirty-one universities responding to Felix Reichmann's survey, only four reported that their libraries did not participate in the selection process. But the majority acknowledged their professional staffs' chief responsibility to be that of filling gaps in serials and purchasing general reading materials. Only two of the thirty-nine reported that libraries suggested titles and purchased in all fields.

The lean times of the 1930s and the hiatus in collection building caused by World War II were followed by a period of accellerated collection growth. Throughout the 1950 s, and particularly in the early 1960 s, some were wondering about the necessity of a new role for professional librarians in light of swelling acquisitions budgets. In 1953, Fussler said, "It is my impression that the number of faculty members who are both able and willing to carry this participation in the actual detailed selection is a diminishing one. ${ }^{\prime \prime 9}$ In a prophetic statement he added, "In many, if not most, of the larger university libraries, the library staff, rather than teaching faculty will increasingly carry the burden of implementing acquisition policy. ${ }^{10}$ Speaking for smaller libraries, Thornton suggested that "while the arbitrary and self-perpetuating allocation of the budget to departments has perhaps kept a sort of peace and assured a rough equity,.... this process may also need careful review." 11

One of the earliest and strongest dissenters to prevailing patterns of selection was Bach. His 1957 article divided book selection policies into three types: those which relied principally on faculty for selection; those-the majority-which speci- 
fied that materials be selected by faculty with the aid and advice of library staff; and those-the minority-which put selection responsibility in the hands of librarians with aid and advice from faculty. Bach applauded the minority in the latter category, calling them the avant-garde of librarianship. ${ }^{2}$

Later, in an essay entitled, "Why Allocate?," ${ }^{\prime 13}$ Bach flatly recommended an end to departmental budgetary allocations. Here he marshalled evidence summarizing the disadvantages of the current system and sparked a lively debate in the literature. But librarians in the 1960s were slow to abandon major faculty involvement in book selection. What did begin to emerge as a pattern was the appointment of staff bibliographers and subject specialists in the larger libraries. As Edelman and Tatum point out in their excellent survey of academic library acquisitions practice, "By the 1960s the scope and size of the selection process had grown well beyond the capabilities of part-time faculty selectors, and one by one each of the larger libraries appointed an in-house selection staff. ${ }^{14}$ Haro, in his survey of university libraries, found that by 1967,69 percent of large libraries used bibliographers or subject specialists. ${ }^{15}$

Clearly a shift was under way-at least in larger libraries. The sheer volume of publication and the growth of acquisitions budgets was forcing a change in librarians' perceptions of their role in book selection. A new stance, one of shared responsibility for adding to subject collections, began to emerge. Librarians began to be concerned with the role of staff bibliographers, creative and cooperative ways of utilizing both library and teaching faculty in the selection process, and joint decision making on purchases. This concern was typified by Schad and Adams who advocated a shared faculty-library strategy to build collections in specific library identified subject areas as an alternative to simply allocating funds to departments. ${ }^{16}$ Wulfekoetter, in her text on acquisitions work, articulated this new viewpoint as well as any, stating that, "book selection is now increasingly a responsibility of the librarian and his staff in conjunction with the faculty in academic libraries. ${ }^{17}$ Lane, in his 1968 survey of the literature, noted a definite shift of opinion from a facultydominant to a library-dominant position in large academic libraries. ${ }^{18}$

In most larger libraries, this idea of shared selection and expenditure responsibilities has become a cornerstone of acquisition policy. Recent literature reflects this thinking, particularly as it relates to university libraries, even though the bountiful flow of funds in the 1960s greatly slowed in the 1970 s and 1980 s.

But what of smaller academic institutions? The results of a survey conducted by Scherer of library-faculty cooperation in 275 small, private, liberal arts colleges documented a "common practice of allocating definite amounts to departments who then made requests for book purchases. ${ }^{19}$ While staffs in university libraries were enlarging to accommodate bibliographic specialists, college library staffs remained static. Perhaps this is why college libraries, without an infusion of subject specialists, have continued to parcel out book funds to academic departments despite the shift in the philosophy and practice of their larger sister institutions. An examination of the recent literature reveals that the old selection orthodoxy still prevails in small college libraries.

Articles by Hellinga, ${ }^{20}$ Carlson, ${ }^{21}$ and Werking and Getchell ${ }^{22}$ illustrate current thought on small college selection procedures. Hellinga concludes that "a small college library, which cannot rely on a staff of trained bibliographers, must either depend upon one or two librarians to keep abreast of all fields (an impossible task!) or it must depend upon the faculty.",23 Carlson states that "a successful library program . . . should be centered about the educational program, which means the acquisitions effort must be faculty centered rather than librarian centered. ${ }^{\prime 24}$ Werking and Getchell assume allocation of funds to faculty and suggest using Choice magazine as a means of determining literature size for allocation purposes.

Recent textbooks on college librarianship and acquisitions, with a single exception, reflect the same thinking. In The 
Small College Library, Sister Helen Sheehan states that, "As soon, however, as the book budget and the number of faculty increase beyond the very minimum, it is necessary to have formal division of funds and some formal arrangements with the faculty for book selection in their subjects." ${ }^{\prime 25}$ In what is perhaps the most commonly used textbook on college librarianship, Lyle states that "in the subjects taught in the college, the job of critical evaluation of specialized books may best be left to scholars in each field. ${ }^{, 26} \mathrm{He}$ further notes that "The concern of the librarian and library staff in selection is principally with reference books, recreational reading, and general books." ${ }^{\prime 27}$ Although Bonk and Magrill, in their work on collection development, advocate shared selection responsibility, they state that "college selection should lean heavily on all faculty members, and full participation should be encouraged by the heads of departments. ${ }^{\prime 28}$

The single exception to this prevailing opinion is that expressed by Miller and Rockwood in a recent collection of essays on college librarianship. They hold that librarians "should secure control of their acquisitions budget if they do not already have it. In too many colleges, academic departments control and expend their budgets to no discernable criteria." ${ }^{29}$ Challenged on this point by another contributor, Miller responded by stating that while the authors endorsed the idea of allocation of library funds, librarians should stand ready "not only to expend departmental funds, but also to exercise judgment on all departmental orders. We do think," he continued, "that librarians should reserve the right to approve every request.",30

To judge by recent research, however, Miller's point of view is a minority one. Small and medium-sized colleges still depend heavily on faculty selection. Futas' 1976 survey of 175 academic libraries of all sizes revealed that "a simple count shows overwhelmingly that faculty are prime initiators [of book orders]. ${ }^{\prime 31}$ Her evidence confirms that while in universities book selection is a shared responsibility and in junior colleges librarians tend to do most of the selection, in small and mediumsized colleges, librarians still rely heavily upon faculty selection as a matter of written policy. ${ }^{32}$

Over the years, arguments for giving faculty primary selection responsibility generally boiled down to three: teaching faculty know the literature of their own subject fields best; only faculty can identify those materials most appropriate for their own study and research; and faculty who teach are best prepared to select course-related materials. There is, of course, some truth to each of these arguments. But all are open to challenge when examined from the perspective of the small college library.

First, it must be remembered that the primary mission of smaller academic institutions is undergraduate instruction, not research. College faculty are primarily teachers, not researchers. Furthermore, the longer they teach at the college level and remain away from graduate schools and research facilities, the more likely they are to lose touch with the scholarship of their fields. This is not an indictment. It simply means that their talents and energies are devoted more to undergraduate teaching than to other scholarly pursuits, including staying abreast of the flood of publications in their subject areas.

Because these faculties do not work with graduate students and because they are most often full-time instructors, their personal need for research materials is less than that of their colleagues at schools with graduate programs. Further, the pressure for publication is less intense at the college level and the corresponding need for library research and graduatelevel materials is modest.

Another important consideration is that in smaller institutions where two, three, and four person departments are common, it is impossible to expect of even the most knowledgeable and diligent faculty currency in all subfields of their respective disciplines. Yet departmental allocation of book budgets assumes this by making them responsible for broad subject areas.

Concerning student book needs, it is clear that teaching faculty know what their students need as assigned reading. 
But librarians are in a far better position to observe what materials students actually use in the library. Most reference librarians would confirm that actual student needs and usage are sharply different from their needs as perceived by their professors. The more intimate and informal student-librarian relationships enhance librarian awareness of student library usage, and circulation records add to their knowledge.

Over the years, a number of librarians have questioned the conventional wisdom that suggests that primary responsibility for book selection ought to reside with teaching faculty. They have cited faculty disinterest, a tendency for faculty to select avidly only in their own narrow fields of study or areas of special interest, the laziness or procrastination of a few, and the inevitable gaps and weaknesses that result from inadequate coordination of acquisitions. Also commonly mentioned are the inflexibility of the allocation process that does not respond quickly to major shifts in curricular need; the touchy problem of having to shrink some allocations and expand others yearly; and the waste that results from the "crash" selection that is required to prevent the loss of funds when some departments fail to expend their allocation by the end of the fiscal year.

No stronger reason for questioning the allocation process has been offered, however, than the one relating to professional responsibility. Many have spoken to this point, but none more cogently than Danton, who asserts, "allocation tends to remove responsibility for book selection from the library where it administratively, philosophically and usually legally belongs, and places it on the faculty, who cannot be responsible or accountable. ${ }^{133}$

Continuity as well as professional responsibility obliges the library to assume selection leadership. It has become increasingly common for colleges to employ part-time and short-term teaching faculty. Continuity in collection building in such situations is very difficult unless the library provides it. Nor can part-time and transient faculty be expected to involve themselves in the ongoing collection eval- uation and preservation efforts so crucial to the maintenance of a strong, up-to-date undergraduate library. Even permanent and full-time faculty who can find the time for consistent attention to evaluation and weeding of the collection are rare.

These reasons for questioning the allocation of book funds remain valid today. In addition, developing circumstances in academic librarianship call ever more urgently for a reexamination of facultylibrary relationships and the role each plays in the book selection process. Today, even very small college libraries are involved in some way with computer applications to technical processes. Many are linked to OCLC for cataloging and interlibrary loan. Others use automated processes for acquisitions. It is highly likely that shared databases and computerized handling of all basic in-house chores soon will be commonplace in all small academic libraries.

These technological changes will have an impact in all areas of library activity, including collection development. Already libraries are linked in sharing networks with instant electronic access to each other's holdings. Networking arrangements and formal resource-sharing agreements will continue to grow, accelerated by expanding electronic and telecommunication capabilities and out of financial necessity. Librarians must concern themselves with network holdings strengths and weaknesses, agreed-upon network acquisition policies, and protocols on collection building commonly arrived at in network compacts. This dynamic and active responsibility cannot be realized if librarians are unwilling to change their historic posture on selection. Common databases and networking mean new selection responsibilities that must be largely incumbent upon librarians. One would expect that as new technologies are put into place, time will become available for them to assume this new role.

It has not been the intent of this essay to minimize the assistance of teaching faculty in the selection process. Their participation is as vital now as it has always been. What is urged is a reevaluation of their role. The selection process must be 
seen as the responsibility of the library faculty, aided and assisted by the teaching faculty, not the other way around.

Shifting this focus will not be easy. The first step must be an abandonment of the departmental apportionment process. There is no reason why the book budget cannot be allocated internally by the library as a means of balancing acquisitions. But such allocation does not have to mean the actual apportioning of funds to departments. There are other means of involving faculty in the selection process, including selection review committees made up of teaching and library faculty, individual bibliographic conferences with faculty, shared use of book reviewing media, subject bibliographies, and annual literature review sessions with individual academic departments.

While finding new ways to involve the teaching faculty in the acquisition recommendation process, librarians must also find ways to convince college administrators of the importance of centering selection decision-making responsibility within the library. With administrators, fiscal and collection quality accountability are beginning points in any statement of rationale. These should be reinforced with an exposition of the new imperatives of shared resources and the impact of new technology. Finally, a written acquisitions policy, arrived at in concert by librarians, teaching faculty, and administrators, can form the solid basis of a new approach to collection building.

Such an approach accords fully with the "Standards for College Libraries" ap- proved by the Association of College and Research Libraries in 1975. The commentary on Standard 2 states that, "although in the last analysis the library must be responsible for the scope and content of the collections, it can best fulfill this responsibility with the help and consultation of the teaching faculty and from students.",34 Clearly, the Standards imply selection leadership and fiscal responsibility by librarians with teaching faculty in a supporting role.

A fundamental goal of academic libraries is the acquisition of materials to meet all reasonable instructional and research needs of faculty and students as well as resources for their general reading. The increasing number and cost of books, the tightening of acquisition budgets, and the widening scope of academic curricula are making the book acquisition process more difficult every year. The appropriate use of available technology and the full utilization of networks and other sharing arrangements will make this task less so. But college librarians, like their colleagues in university libraries, also need to begin to take control of their own book budgets. When a one-hundred-dollar bill scarcely will purchase four monographic works, and when every book selected also means one not selected, we must exercise increasingly careful stewardship over our precious monetary resources. Surely such stewardship does not include putting a large share of our funds and the accompanying selection authority into other hands.

\section{REFERENCES}

1. J. Perian Danton, Book Selection and Collections: A Comparison of German and American Universities (New York: Columbia Univ. Pr., 1963).

2. Ibid., p.30.

3. American Library Association, Suroey of Libraries in the United States, V.1 (Chicago: American Library Assn., 1926), p.237.

4. U.S. Office of Education, "Survey of Land Grant Colleges and Universities," Bulletin, no.9 (Washington, D.C.: Govt. Print. Off., 1930), p.652.

5. William M. Randall, The College Library (Chicago: American Library Assn., 1932), p.106.

6. Danton, "The Faculty, the Librarian, and Book Selection," Library Journal 61:715-16 (Oct. 1, 1936); Nathan Van Patten, "Buying Policies of College and University Libraries," College and University Libraries 1:64-71 (Dec. 1939).

7. American Library Association and Association of College and Reference Libraries, College and 
University Post-War Planning Committee, College and University Libraries and Librarianship (Chicago: American Library Assn., 1946), p.36.

8. Felix Reichmann, "Management and Operation," Library Trends 3:463 (April 1955).

9. Herman H. Fussler, "Acquisition Policy: Larger University Libraries," College \& Research Libraries 14:365 (Oct. 1953).

10. Ibid.

11. Eileen Thornton, "Acquisition Policy: The Small College Library," College \& Research Libraries 14:371 (Oct. 1953).

12. Harry Bach, "Acquisition Policy in the American Academic Library," College \& Research Libraries 18:441-51 (Nov. 1957).

13. Bach, "Why Allocate?," Library Resources \& Technical Services 8:161-65 (Spring 1964).

14. Hendrick Edelman and G. Marvin Tatum, Jr., "The Development of Collections in American University Libraries," College \& Research Libraries 37:236 (May 1976).

15. Robert P. Haro, "Book Selection in Academic Libraries," College \& Research Libraries 28:104-106 (March 1967).

16. Jasper G. Schad and Ruth L. Adams, "Book Selection in Academic Libraries: A New Approach," College \& Research Libraries 30:437-42 (Sept. 1969).

17. Gertrude Wulfekoetter, Acquisition Work: Processes Involved in Building Library Collections (Seattle: Univ. of Washington Pr., 1961), p.21.

18. David O. Lane, "The Selection of Academic Library Materials, A Literature Survey," College \& Research Libraries 29:371 (Sept. 1968).

19. Henry Scherer, "The Faculty and the Librarian," Library-College Journal 3:41 (Fall 1970).

20. Robert R. Hellinga, "Departmental Acquisitions Policies for Small College Libraries," Library Acquisitions 3:81-84 (1979).

21. James F. Carlson, "Book Selection and the Small College Library," Learning Today 4:37-43 (Fall 1971).

22. Richard H. Werking and Charles M. Getchell, Jr., "Using Choice as a Mechanism for Allocating Book Funds in an Academic Library," College \& Research Libraries 42:134-38 (March 1981).

23. Hellinga, "Departmental Acquisitions Policies for Small College Libraries," p.82.

24. Carlson, "Book Selection and the Small College Library," p.38.

25. Sister Helen Sheehan, The Small College Library, rev. ed. (Washington, D.C.: Corpus Books, 1969), p.41.

26. Guy R. Lyle, Administration of the College Library, 4th ed. (New York: Wilson, 1974), p.177.

27. Ibid., p.179.

28. Wallace John Bonk and Rose Mary Magrill, Building Library Collections, 5th ed. (Metuchen, N.J.: Scarecrow, 1979), p.38.

29. William Miller and Stephen Rockwood, "Collection Development from a College Perspective," in College Librarianship, William Miller and Stephen Rockwood, eds., (Metuchen, N.J.: Scarecrow, 1981), p.144-45.

30. William Miller, "Collection Development: A Response," in College Librarianship, Miller and Rockwood, p.153.

31. Elizabeth Futas, Library Acquisitions Policies and Procedures (Phoenix, Ariz.: Oryx, 1977), p.xxi.

32. Ibid., p.159-248.

33. Danton, Book Selection and Collection, p.69.

34. ACRL Ad Hoc Committee to Revise the 1959 Standards, "Standards for College Libraries," College \& Research Libraries News 36:290 (Oct. 1975). 